\title{
Residency, demographics, and movement patterns of North Atlantic right whales Eubalaena glacialis in an offshore wind energy development area in southern New England, USA
}

\author{
E. Quintana-Rizzo ${ }^{1,5, *}$, S. Leiter ${ }^{1}$, T. V. N. Cole ${ }^{2}$, M. N. Hagbloom ${ }^{1}$, A. R. Knowlton ${ }^{1}$, \\ P. Nagelkirk ${ }^{1}$, O. O'Brien ${ }^{1}$, C. B. Khan ${ }^{2}$, A. G. Henry ${ }^{2}$, P. A. Duley ${ }^{2}$, L. M. Crowe ${ }^{3}$, \\ C. A. Mayo $^{4}$, S. D. Kraus ${ }^{1}$ \\ ${ }^{1}$ Anderson Cabot Center for Ocean Life, New England Aquarium, Boston, MA 02110, USA \\ ${ }^{2}$ Northeast Fisheries Science Center, National Marine Fisheries Service, National Oceanic and Atmospheric Administration, \\ Woods Hole, MA 02543, USA \\ ${ }^{3}$ Integrated Statistics, under contract to the Northeast Fisheries Science Center, National Marine Fisheries Service, \\ National Oceanic and Atmospheric Administration, Woods Hole, MA 02543, USA \\ ${ }^{4}$ Center for Coastal Studies, Provincetown, MA 02657, USA \\ ${ }^{5}$ Present address: Simmons University, Boston, MA 02115, USA
}

\begin{abstract}
Offshore wind energy development is growing quickly around the world. In southern New England, USA, one of the largest commercial offshore wind energy farms in the USA will be established in the waters off Massachusetts and Rhode Island, an area used by the Critically Endangered North Atlantic right whale Eubalaena glacialis. Prior to 2011, little was known about the use of this area by right whales. We examined aerial survey data collected between 2011-2015 and 2017-2019 to quantify right whale distribution, residency, demography, and movements in the region. Right whale occurrence increased during the study period. Since 2017, whales have been sighted in the area nearly every month, with peak sighting rates between late winter and spring. Model outputs suggest that $23 \%$ of the species' population is present from December through May, and the mean residence time has tripled to an average of $13 \mathrm{~d}$ during these months. Age and sex ratios of the individuals present in the area are similar to those of the species as a whole, with adult males the most common demographic group. Movement models showed that southern New England is an important destination for right whales, including conceptive and reproductive females, and qualitative observations included animals feeding and socializing. Implementing mitigation procedures in coordination with these findings will be crucial in lessening the potential impacts on right whales from construction noise, increased vessel traffic, and habitat disruption in this region.
\end{abstract}

KEY WORDS: Migratory species · Alternative energy $\cdot$ Aerial surveys

\section{INTRODUCTION}

The management and conservation of migratory species is challenging, particularly in dynamic marine environments. Many factors influence a species' presence, so it is difficult to predict how and when a

${ }^{*}$ Corresponding author: tetequintana@comcast.net

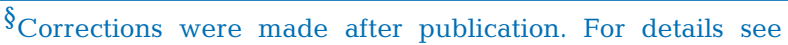
www.int-res.com/abstracts/esr/v45/c_p251-268/

This corrected version: August 6, 2021 species may utilize an area and whether conservation actions are necessary. Anthropogenic stressors can also affect a species' presence or residency and impact the quality of suitable habitats throughout the migratory route needed for the species' breeding, food, and shelter (Runge et al. 2014). Thus, the effec-

(C) The authors 2021. Open Access under Creative Commons by Attribution Licence. Use, distribution and reproduction are unrestricted. Authors and original publication must be credited.

Publisher: Inter-Research · www.int-res.com 
tive conservation of migratory species requires an understanding of how, when, and which individuals use different migratory pathways and habitats as well as the potential stressors throughout their range.

The North Atlantic right whale Eubalaena glacialis (hereafter referred to as the right whale) is a Critically Endangered migratory species (Cooke 2020). It is also one of the most endangered cetaceans worldwide, with an estimated abundance of 356 individuals (Pettis et al. 2021). The population has been declining since 2010 (Pace et al. 2017, Pettis et al. 2020) due to mortality from entanglements in fixed fishing gear and vessel strikes (Corkeron et al. 2018, Sharp et al. 2019, Pace et al. 2021) and a $40 \%$ decrease in calving (Kraus et al. 2016a), including no births in 2018 (Pettis et al. 2020). This decrease in reproduction may be attributable to chronic stress from anthropogenic injury (van der Hoop et al. 2017) and climate-driven changes in food resources (MeyerGutbrod et al. 2018, Record et al. 2019).

Whaling records indicate that right whales once inhabited both sides of the North Atlantic (IWC Int 2001), but today the remaining population is seen almost exclusively along the east coast of the USA and Canada, from Florida to the Gulf of St. Lawrence, with infrequent sightings in the Gulf of Mexico and the eastern North Atlantic (Kraus \& Rolland 2007, Firestone et al. 2008, Ward-Geiger et al. 2011). Since 2010, their presence has declined in and around once key habitats in the Gulf of Maine and Bay of Fundy (Davies et al. 2015, 2017), while sightings have increased in other areas including Cape Cod Bay, Massachusetts Bay, the Mid-Atlantic Bight, and the Gulf of St. Lawrence (Whitt et al. 2013, Davis et al. 2017, Mayo et al. 2018, Davies et al. 2019, Ganley et al. 2019, Charif et al. 2020). These shifts in distribution have been correlated with changes in oceanographic conditions and food supply (Record et al. 2019) and have resulted in increased exposure to anthropogenic impacts as the whales move into areas with little or no protective measures (Davies \& Brillant 2019). The shifts have prompted the need for increased monitoring efforts to track right whale distribution, especially in areas where anthropogenic pressures are expanding.

Right whale movements across habitats have conservation implications (Brillant et al. 2015) nationally and internationally, as their travel and residency patterns expose them to various anthropogenic activities. Regulations to protect right whales have been implemented in the USA and Canada. Both countries have established critical habitats, which are areas considered to contain physical and biological features essential to the species' conservation (USA:
NMFS 2016) or 'the habitat necessary for the survival or recovery of a listed wildlife species and that is identified as the species' critical habitat in the recovery strategy or in an action plan for the species' (Canada: Brown et al. 2009, Fisheries and Oceans Canada 2014). Within the USA, the Gulf of Maine-Georges Bank critical habitat is considered an important feeding habitat, and the southeastern coast is a critical habitat for calving (NMFS 2016). In Canada, the Bay of Fundy and Roseway Basin are critical feeding habitats (Fisheries and Oceans Canada 2014). These areas were considered to be of primary importance to the whales, but feeding and calving have also been observed outside the established critical habitats (Patrician et al. 2009, Foley et al. 2011). Thus, predicting the species' spatiotemporal distribution is vital in the management of human activities where whales and threats co-occur.

Right whales were first systematically recorded in southern New England (SNE) waters between 2011 and 2015 (Kraus et al. 2016b, Leiter et al. 2017, Stone et al. 2017). Little was known about the use of this area by right whales prior to this monitoring effort, although a large influx of 102 right whales was documented on 20 April 2010 by Northeast Fisheries Science Center (NEFSC) surveys (Khan et al. 2011), and models suggested the SNE region was suitable right whale habitat (Pendleton et al. 2012). SNE is near other right whale habitats, including the Great South Channel, Cape Cod Bay, and the mid-Atlantic migratory corridor (Schick et al. 2009, Whitt et al. 2013) connecting the northeastern feeding grounds with the calving grounds in the southeastern USA. The 20112015 monthly visual and acoustic monitoring effort found consistent use of the area by a significant portion of the right whale population, a strong correlation between season and presence, and a peak abundance in the spring (Kraus et al. 2016b, Leiter et al. 2017). Over one-third of the right whale population and $30 \%$ of the presumed living calving females known at the time were documented during these surveys (Leiter et al. 2017).

The regular presence of right whales in SNE deserves more attention. Since SNE will become one of the largest commercial offshore wind energy leases along the US east coast, the consequences of the construction and operation are relevant to the conservation of the species. The effects of offshore wind development on right whales are unknown (Madsen et al. 2006), but this enormous development could have a local impact on right whales at a critical time when they are becoming more reliant on the region (Leiter et al. 2017). The construction and maintenance of hun- 
dreds of wind turbines could cause habitat changes (Wilhelmsson et al. 2006) and influence oceanographic conditions and water column stratification (Broström 2008, Paskyabi \& Fer 2012, Paskyabi 2015, Segtnan \& Christakos 2015). Both construction and maintenance activities may also expose right whales to higher levels of vessel traffic as well as increased noise. Increased vessel traffic will result in a greater risk of vessel strikes with right whales. In addition, low-frequency noise from large ships (20-200 Hz) overlaps acoustic signals used by right whales (Hatch et al. 2012). Collectively, these perturbations could affect the use of this region by right whales as well as influence their migratory movements throughout the midAtlantic region (Schick et al. 2009).

Here, we present an extended assessment of the distribution, demography, residency, and movements of right whales observed in the SNE region over 2 survey periods (2011-2015 and 2017-2019). We discuss the management implications of this study and include recommendations for future conservation management plans for this and other offshore wind energy development areas.

\section{MATERIALS AND METHODS}

\subsection{Field effort and right whale identifications}

The study area included SNE waters from the shores of Martha's Vineyard and Nantucket, including Nantucket Shoals, Massachusetts, USA, to approximately $90 \mathrm{~km}$ south, and encompassed all the lease sites for Massachusetts and Rhode Island wind energy development. Geographically, the study area lies between $40.50^{\circ}$ and $41.33^{\circ} \mathrm{N}$ latitude and $71.40^{\circ}$ and $69.50^{\circ} \mathrm{W}$ longitude (Fig. 1A). The New England Aquarium (NEAq) conducted systematic aerial surveys in this region, while NEFSC and the Center for Coastal Studies (CCS) conducted directed surveys to areas of right whale presence. Although the level of effort, spatial extent, and configuration of the 3 survey platforms varied, the flights were line transect surveys conducted from a high-winged aircraft (Cessna 337 Skymaster O-2A, high-wing Cessna 336, or Havilland DHC-6 Twin Otter) with 2 experienced observers positioned on either side of the plane. Surveys were flown under visual flight rules at
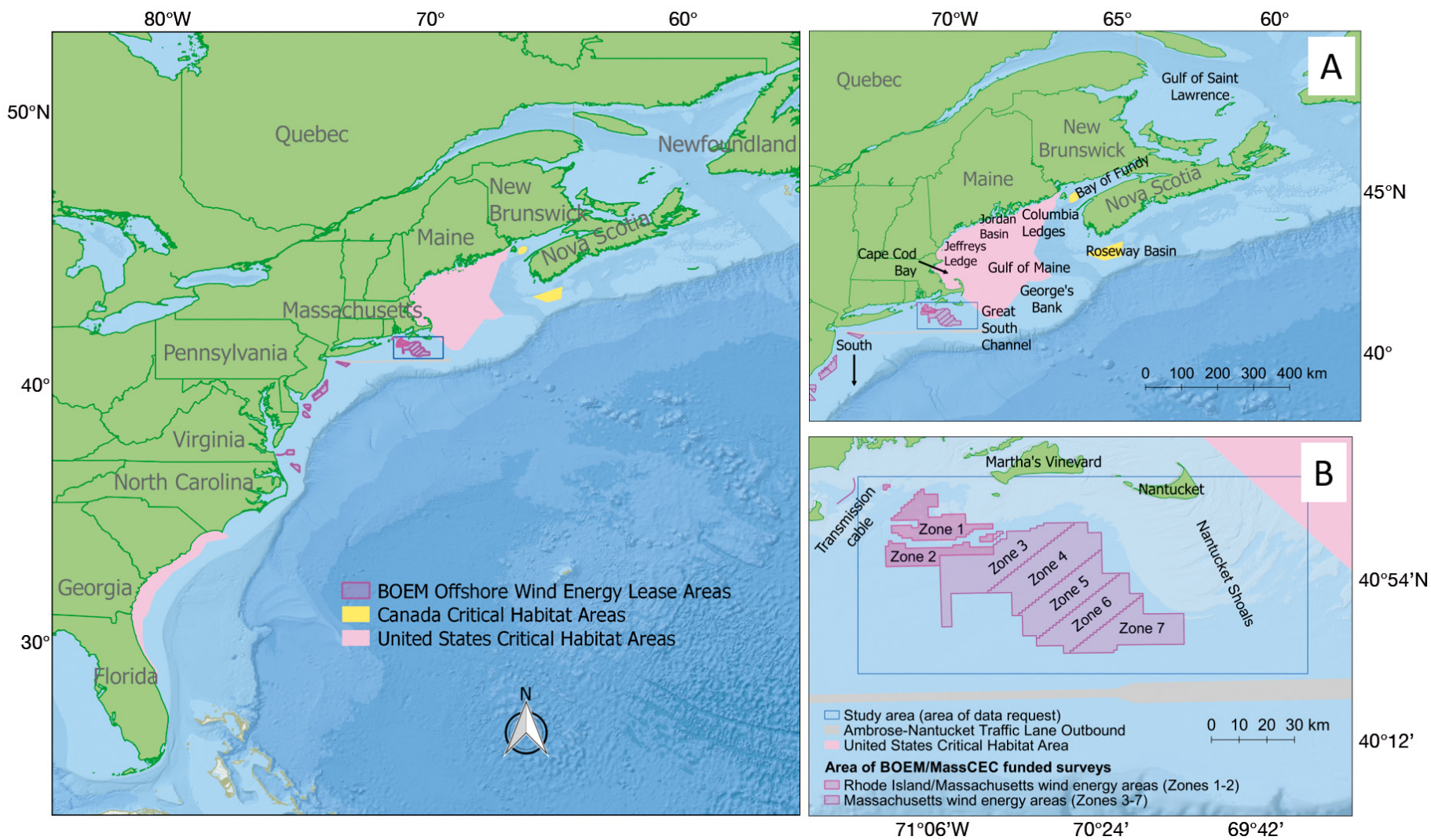

Fig. 1. Right whale critical habitats in the USA and Canada, and offshore wind energy lease areas. (A) Habitats studied in the analysis of right whale movement patterns. South covers the area from New York to Florida. (B) Study area south of Martha's Vineyard and Nantucket, Massachusetts, USA, which encompasses the Rhode Island-Massachusetts and Massachusetts wind energy areas. BOEM: Bureau of Ocean Energy Management; MassCEC: Massachusetts Clean Energy Center 
an altitude of 229 to $305 \mathrm{~m}$ and a target groundspeed of $185 \mathrm{~km} \mathrm{~h}^{-1}$. Preferred environmental conditions included a minimum ceiling of $610 \mathrm{~m}$, visibility $>9 \mathrm{~km}$, wind speed $<10$ knots, and Beaufort sea state $\leq 4$. Flight parameters (e.g. time, latitude, longitude, altitude, speed) were recorded every 2 to $5 \mathrm{~s}$ throughout the surveys, and when right whales were sighted, the plane broke from the trackline and circled the whales to obtain photographs for individual identification. The plane continued the line transect survey after obtaining images of all right whales present in the area. Sighting and photographic data were collected in accordance with North Atlantic Right Whale Consortium (NARWC) Sightings database guidelines (Kenney 2019). Individual right whales were identified by distinctive callosity patterns on their head, lips, and chin and by scars (Kraus et al. 1986). Right whale photographs were integrated into the NARWC Identification database (Hamilton et al. 2007) and matched to cataloged individuals.

\subsection{Datasets and statistical analysis}

The data were divided into 2 time periods, 20112015 (early years) and 2017-2019 (recent years). No surveys were conducted by NEAq in the study area in 2016. We reanalyzed portions of the 2011-2015 data from Leiter et al. (2017) because the study area was expanded in 2017-2019. The NARWC provided 3 datasets to support various analyses investigating right whale use in SNE (NARWC 2019, 2020). Dataset 1 included only right whale sightings and survey effort collected by the NEAq aerial surveys in the study area during both study periods. This dataset was used to identify clustered distribution areas and calculate sighting rates of right whales in SNE. Dataset 2 included the photographed sightings, demographics, and behavior of identified individual right whales collected during systematic surveys and directed effort conducted by all survey teams in SNE. Verification of individual right whale identifications for 2019 was not completed at the time of writing and was omitted from the analysis. Dataset 2 was used for residency and demographic analyses to calculate the percentage of right whales of the current population sighted in SNE, to summarize general behavioral activities, and to create a discovery curve of the individual right whales photographed in the study area. Discovery curves were created to obtain a cumulative count of distinct individuals over time and to provide insights into whether this population was opened or closed (Wilson et al. 1999). Behavioral activities were not quantified because the information was not always collected; however, observations of feeding and socializing were summarized. Surface or nearsurface feeding was defined as an observation during which observers could see a right whale swimming open mouthed at or beneath the surface (Mayo et al. 2018). Socializing included surface active groups, which are defined as 2 or more whales rolling and touching at the surface (Kraus \& Hatch 2001, Parks et al. 2007a). Dataset 3 included the sighting history of individual right whales observed during systematic surveys and directed effort in SNE by all contributors. This dataset was used to assess right whale movements to and from SNE and other locations in the North Atlantic during the 2011-2015 and 2017-2018 periods. Descriptive statistics were reported as mean $\pm \mathrm{SE}$ for continuous variables and $\mathrm{N}(\%)$ for categorical variables.

\subsubsection{Distribution}

Distribution and sighting rates were calculated using the standardized systematic survey data in Dataset 1. Effort was defined as the total kilometers flown including transects, circling, cross-legs, and transits (Kraus et al. 2016b, Leiter et al. 2017). Species identification confidence levels of definite (high confidence in species identification) or probable (moderate confidence, Kenney 2019) were included in the analysis. Sighting rates were calculated as the number of right whales sighted per $1000 \mathrm{~km}$ of survey effort on a per-month basis to examine temporal trends in the number of whales visiting the study area. Monthly sighting rates across all years were examined using a Kruskal-Wallis test, and multiple Mann-Whitney $U$ post hoc tests were used to compare differences between years. The 2-tailed statistical tests were conducted using the SPSS 26.0 package (2019) at a significance level of 0.05. Temporal and spatial analyses of sighting rates assumed that non-systematic periods such as circling were distributed sufficiently homogeneously that a substantial bias was not incurred.

A hotspot analysis was used to delineate the seasonal clustered distribution of right whales within the study area for the 2 study periods (2011-2015 and 2017-2019) using QGIS 3.10.6 (QGIS Development Team 2018). The study area was divided into equally sized grids of $7 \times 7 \mathrm{~km}$ cells. Sighting rates per survey (number of right whales sighted per $1000 \mathrm{~km}$ ) were assigned to each corresponding cell, and a hotspot analysis was performed to test for statistically signifi- 
cant spatial clustering of right whales by seasons in the early and recent years of the study using the QGIS Hotspot Analysis plugin (Oxoli et al. 2017). This plugin implements the Getis-Ord $\mathrm{Gi}^{*}$ statistic to detect atypical clusters of high (hotspots) or low (coldspots) values by looking at a cell value in the context of its neighbors' values (Getis \& Ord 1992, Oxoli et al. 2017). Seasons were defined as winter (DecemberFebruary), spring (March-May), summer (JuneAugust), and fall (September-November). Only season-period combinations with greater than 10 right whale sightings were used, as smaller sample sizes are considered insufficient for statistical analysis (Ott 1994). Seasonal maps were compiled for each study period at 3 levels of confidence $(99,95$, and 90\%), and all clusters that were within the $90 \%$ confidence level were considered hotspots.

\subsubsection{Demographics}

NARWC (2020) provided sex and age class (calf, juvenile, adult, unknown) information for the individual right whales sighted in the study area (Dataset 2). Only juvenile (defined as whales that are 1-8 yr old) and adult (defined as whales that are 9 yr of age or older, were not seen as calves but initial sighting was at least 8 yr prior, or were known to be reproductive; Hamilton et al. 1995) age classes were examined. Unknowns and dependent calves were excluded because the number of sightings was too small $(\mathrm{n}<10$ ) for statistical comparisons. A G-test of independence was used to determine if the sex and age ratios differed from year to year, and the annual age and sex ratios were compared to the corresponding annual ratios of the population using individual G-tests of goodness of fit with a Bonferroni correction (after Mayo et al. 2018). Population ratios were calculated using the minimum number of right whales presumed alive in a given year following Knowlton et al. (1994).

Since right whales were present in this region at the time of year when conception is expected for this species (Cole et al. 2013), life history characteristics of the males and females were investigated. Paternity is determined through molecular analysis (Frasier et al. 2007), and for this study, genetic analysis of known fathers was only available for the first $3 \mathrm{yr}$. Both the proportion of reproductive females and the proportion of conceptive females compared to all identified females present in SNE were calculated for each year. Females that had given birth in the years prior to or in the year of a recorded sighting were considered reproductive (Kraus et al. 2001). Females were considered conceptive for a year beginning in March, 2 yr before giving birth (Cole et al. 2013). For instance, a female first sighted with a calf anywhere along the North Atlantic between December 2014 and November 2015 would be considered conceptive during the period 1 March 2013 through 1 March 2014.

\subsubsection{Residence}

Residence was defined as the minimum number of days that an individual whale was in SNE (BarachoNeto et al. 2012). To determine the residency of right whales in the study area, maximum likelihood methods were used to determine the lagged identification rate, i.e. the probability that an individual right whale will be resighted in the study area after a time lag using Dataset 2 (Whitehead 2001). This method allows for non-random distribution of sampling effort (Whitehead 2007, 2009) and the incorporation of individual identification data obtained during both systematic and directed surveys.

Empirical lagged identification rate data were compared to a series of movement models representing closed and open populations implemented in the program SOCPROG 2.9 (Whitehead 2009) (Table 1a). These models provide an estimate of the number of visitors in the study area based on mark-recapture probabilities (Whitehead 2001). SOCPROG includes 2 closed population models, but only one of those models (A) was applied because SNE appeared to be an open population, as the discovery curve indicated that new right whales were identified in the study area over time, and the 2 models provided similar results to this dataset. The following pairs of open models are structurally identical but parameterized differently: B and D, C and F, and E and G (Table 1). This order represents the order in which the program generates the results when the models are run simultaneously. All models were run simultaneously so that the variance inflation factor could be taken from the most general model and applied to all of them (Whitehead 2009). Model selection was based on the lowest Akaike's information criterion (AIC) when the data were overdispersed (Whitehead 2007); otherwise, the lowest quasi-AIC (QAIC) was used, and model fits were bootstrapped 100 times to generate SEs for the lagged identification rate estimates.

The lagged identification rate was calculated from the best-fit model applied to sighting data collected from December to May, the period when previous 
Table 1. (a) Models and parameters and (b) fits and comparison for lagged identification rate of all right whales, females, and males in southern New England during 2 time periods. AIC: Akaike's information criterion; QAIC: quasi-AIC

\begin{tabular}{|c|c|c|c|c|c|c|}
\hline Model & \multicolumn{6}{|c|}{ Model type and parameters } \\
\hline A & \multicolumn{6}{|c|}{ Closed (1/a1 $=\mathrm{N}$ or number of visitors) } \\
\hline B & \multicolumn{6}{|c|}{ Emigration/mortality $(\mathrm{a} 1$ = emigration rate; $1 / \mathrm{a} 2=\mathrm{N}$ ) } \\
\hline $\mathrm{C}$ & \multicolumn{6}{|c|}{$\begin{array}{l}\text { Emigration }+ \text { reimmigration }(\mathrm{a} 1=\text { emigration rate; } \mathrm{a} 2 /(\mathrm{a} 2+\mathrm{a} 3)=\text { proportion of population in study area at } \\
\text { any time) }\end{array}$} \\
\hline D & \multicolumn{6}{|c|}{ Emigration/mortality ( $\mathrm{a} 1=\mathrm{N} ; \mathrm{a} 2=$ mean residence time) } \\
\hline E & \multicolumn{6}{|c|}{ Emigration + reimmigration + mortality } \\
\hline $\mathrm{F}$ & \multicolumn{6}{|c|}{ Emigration + reimmigration $(\mathrm{a} 1=\mathrm{N} ; \mathrm{a} 2=$ mean time in study area $; \mathrm{a} 3=$ mean time out of study area $)$} \\
\hline $\mathrm{G}$ & \multicolumn{6}{|c|}{$\begin{array}{l}\text { Emigration + reimmigration }+ \text { mortality }(\mathrm{a} 1=\mathrm{N} ; \mathrm{a} 2=\text { mean time in study area; } \mathrm{a} 3=\text { mean time out of study } \\
\text { area; } \mathrm{a} 4=\text { mortality rate })\end{array}$} \\
\hline \multirow{2}{*}{$\begin{array}{l}\text { b. } \\
\text { Model }\end{array}$} & & \multicolumn{2}{|c|}{ - Female } & \multicolumn{2}{|c|}{ - Male } \\
\hline & $\begin{array}{c}\text { AIC } \\
2011-2015\end{array}$ & $\begin{array}{c}\text { QAIC } \\
2017-2018\end{array}$ & $\begin{array}{c}\text { AIC } \\
2011-2015\end{array}$ & $\begin{array}{c}\text { QAIC } \\
2017-2018\end{array}$ & $\begin{array}{c}\text { AIC } \\
2011-2015\end{array}$ & $\begin{array}{c}\text { QAIC } \\
2017-2018\end{array}$ \\
\hline A & 357.32 & 1490.84 & 154.68 & 504.23 & 357.50 & 496.68 \\
\hline B & 356.30 & 1476.94 & 154.47 & 504.88 & 891.58 & 487.30 \\
\hline $\mathrm{C}$ & 360.39 & $1458.85^{\mathrm{a}}$ & 156.74 & $496.26^{\mathrm{a}}$ & $356.94^{\mathrm{a}}$ & $479.89^{\mathrm{a}}$ \\
\hline D & 356.30 & 1476.94 & 154.47 & 504.89 & 358.06 & 487.30 \\
\hline E & 359.79 & 1466.59 & 157.70 & 497.96 & 359.06 & 486.63 \\
\hline $\mathrm{F}$ & $351.20^{\mathrm{a}}$ & $1458.85^{\mathrm{a}}$ & $153.40^{\mathrm{a}}$ & $496.26^{\mathrm{a}}$ & $356.94^{\mathrm{a}}$ & $479.89^{\mathrm{a}}$ \\
\hline G & 352.89 & 1460.84 & 523.78 & 502.68 & 358.72 & 482.91 \\
\hline
\end{tabular}

studies identified a high right whale presence in the area (Kraus et al. 2016b, Leiter et al. 2017). Residency was estimated for the 2 time periods (2011-2015 and 2017-2018) to determine if it changed over time. The lagged identification rates were calculated, and models fitted, for males and females separately to investigate whether the sexes exhibited different residency patterns. The number of right whale identifications for summer and fall was too low to calculate a separate lagged identification rate, but the percentages of individual right whales sighted in the summer and fall were calculated. These models have been used for cetaceans (e.g. Wimmer \& Whitehead 2004, Dinis et al. 2016, Chabanne et al. 2017) and other migratory marine megafauna (e.g. manta rays: Deakos et al. 2011, whale sharks: McKinney et al. 2017, McCoy et al. 2018).

\subsubsection{Movements}

Dataset 3 was used to estimate the seasonal transition probabilities between SNE and other areas for both study periods. The analysis was limited to the movements between SNE and no more than 4 areas to ensure precise estimates given by the small number of habitat comparisons and the high number of identified individuals moving among areas (Whitehead 2009). The areas followed Brillant et al. (2015) and included, from north to south, the Gulf of St. Lawrence, Bay of Fundy, Gulf of Maine (including the Columbia and Jeffreys ledges and Jordan Basin), Cape Cod Bay, Great South Channel-Georges Bank, and the South (from New York to Florida) (Fig. 1B). The mid-Atlantic was combined with adjacent areas to the south to increase the sample size.

Transition probabilities were calculated using a parameterized Markov movement model in SOCPROG 2.9 (Whitehead 2009). This populationscale behavior model uses the locations and each time unit of photographically identified individuals to estimate the probability of moving from one area to another at a time lag (Whitehead 2001). This model can be used with identifications that are not distributed randomly or uniformly in space or time and that have no independent measure of effort (Whitehead 2001). The small number $(\mathrm{n}<10)$ of seasonal right whale identifications in SNE in fall and summer 2011-2015 did not permit the estimation of transition probabilities for those seasons. A $30 \mathrm{~d}$ lag was used 
based on the assumption that an identified right whale in any location could reach any of these other habitats within this interval (Brillant et al. 2015, Davies et al. 2015) during the season of interest. Back-and-forth movements of right whales between southern New England and nearby areas were explored by examining the sighting histories of individual right whales.

\section{RESULTS}

\subsection{Field effort, right whale identifications, and behavioral activities}

The combined survey effort in southern New England covered $111440 \mathrm{~km}$ between March 2011 and December 2019 (Table 2). The annual tally of right whales reported (not unique whale identifications) from all sightings varied between 28 and 418 (144 \pm 49 whales). A total of 327 unique right whales were identified, with a mean number of 9 identifications per survey day. At least 16 of these whales were confirmed dead according to NARWC as of the beginning of December 2020. The discovery curve showed an increasing trend in the number of new individuals sighted, with no clear plateau signal (Fig. 2), and by the end of $2019,87 \%$ of the current population had been sighted in SNE throughout the study period. The discovery curve had a steep slope during the 2011-2015 surveys and was even steeper in 20172018, suggesting an open population or that sightings in the area were underestimated. Feeding was recorded on more occasions ( $\mathrm{n}=190$ occasions) than socializing ( $\mathrm{n}=59$ occasions). Feeding was observed in all seasons and years, whereas social behaviors were observed mainly in the winter and spring and were not observed in 2011 and 2017.

\subsection{Datasets and statistical analysis}

\subsubsection{Distribution}

Sighting rates varied through time, suggesting that right whales have become more common in recent years and that their presence now extends beyond the December-May period in SNE. No right whales were reported in 2011 in Dataset 1, but the NEAq surveys did not start until October that year. Sighting rates varied in most other years (Fig. 3; KruskalWallis test $=20.67$, df $=6, p=0.002$ ). Pairwise comparisons showed that the sighting rates of right
Table 2. Total tally of right whales recorded in all sightings (no ID included), unique ID, population percentage sighted in relation to the general right whale population (based on Pace et al. 2017 and Pettis et al. 2021 updated population estimates), and annual survey effort $(\mathrm{km})$ in southern New England waters by main data contributors. NEAq: New England Aquarium; NEFSC: Northeast Fisheries Science Center; CCS: Center for Coastal Studies; NA: not available at the time of the data request; $\mathrm{NC}$ : not calculated (number of unique IDs not available); (-) no data

\begin{tabular}{|ccrrrrr|}
\hline Year & $\begin{array}{c}\text { Tally of } \\
\text { right } \\
\text { whales }\end{array}$ & $\begin{array}{c}\text { Unique } \\
\text { ID }\end{array}$ & $\begin{array}{c}\text { \% of } \\
\text { population } \\
\pm \text { SE }\end{array}$ & $\begin{array}{c}\text { NEAq } \\
(\mathrm{km})\end{array}$ & $\begin{array}{c}\text { NEFSC } \\
(\mathrm{km})\end{array}$ & $\begin{array}{c}\text { CCS } \\
(\mathrm{km})\end{array}$ \\
\hline 2011 & 83 & 53 & $11 \pm 1$ & 4279 & 2455 & 327 \\
2012 & 28 & 22 & $5 \pm 1$ & 16042 & 1471 & - \\
2013 & 32 & 20 & $4 \pm 1$ & 12890 & 779 & - \\
2014 & 44 & 43 & $9 \pm 1$ & 17279 & 1763 & - \\
2015 & 86 & 53 & $11 \pm 1$ & 9594 & 6761 & 357 \\
2017 & 214 & 122 & $29 \pm 2$ & 18867 & 2456 & - \\
2018 & 418 & 202 & $53 \pm 2$ & 11295 & 9732 & - \\
2019 & 250 & NA & NC & 20729 & NA & - \\
\hline
\end{tabular}

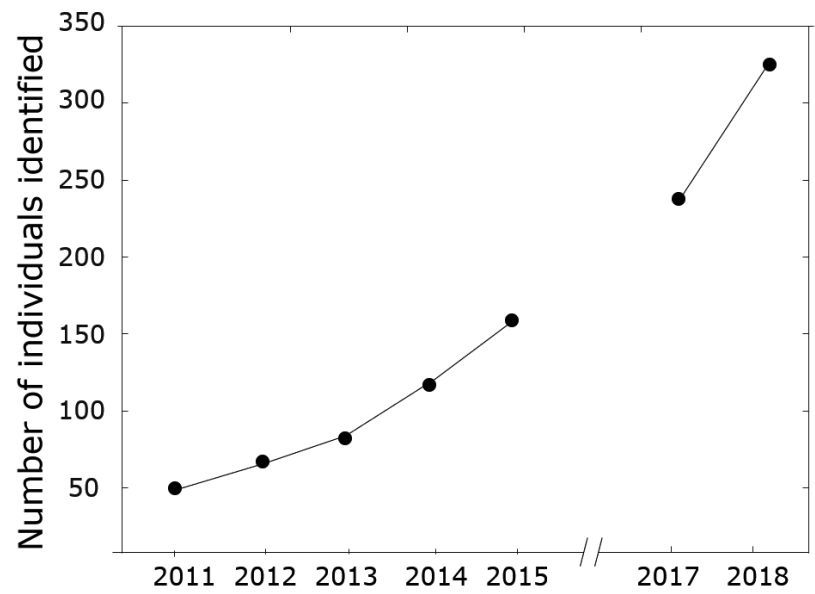

Fig. 2. Discovery curve for the number of uniquely identified individual right whales sighted in southern New England. The slope of the curve indicates an open population where not all individuals have been sampled. No field effort was conducted in 2016

whales were not significantly different among the early years of the study, and the sighting rates of most of those years were lower than those of recent years (Fig. 3). Sighting rates were not statistically different in 2015, 2017, and 2018 (Fig. 3). Right whale sightings by month were highest from January to April during the early years of the study, but in recent years, right whales were sighted in most months of the year, with notably high sighting rates in December 2018 and August 2019 (Fig. 4).

The seasonal clustered distribution of right whales varied in space and time and extended into wind 


\begin{tabular}{|c|c|c|c|c|c|c|c|c|}
\hline & & $A: M$ & ann-Wh & itney U- & est sta & istical v & alues & \\
\hline & Year & 2012 & 2013 & 2014 & 2015 & 2017 & 2018 & 2019 \\
\hline & 2012 & & 49.50 & 56.00 & 16.00 & 26.50 & 18.00 & 7.50 \\
\hline of & 2013 & 0.96 & & 56.00 & 15.00 & 27.50 & 19.00 & 10.50 \\
\hline & 2014 & 0.75 & 0.75 & & 22.00 & 41.00 & 30.00 & 10.00 \\
\hline I & 2015 & 0.21 & 0.17 & 0.34 & & 27.00 & 18.00 & 9.00 \\
\hline & 2017 & $0.04^{*}$ & $0.04^{*}$ & 0.10 & 0.95 & & 43.00 & 18.50 \\
\hline & 2018 & $0.01^{*}$ & $0.01^{*}$ & $0.04^{*}$ & 0.39 & 0.39 & & 24.00 \\
\hline & 2019 & $0.002^{*}$ & $0.006^{*}$ & $0.002^{*}$ & 0.11 & $0.03^{*}$ & 0.15 & \\
\hline
\end{tabular}

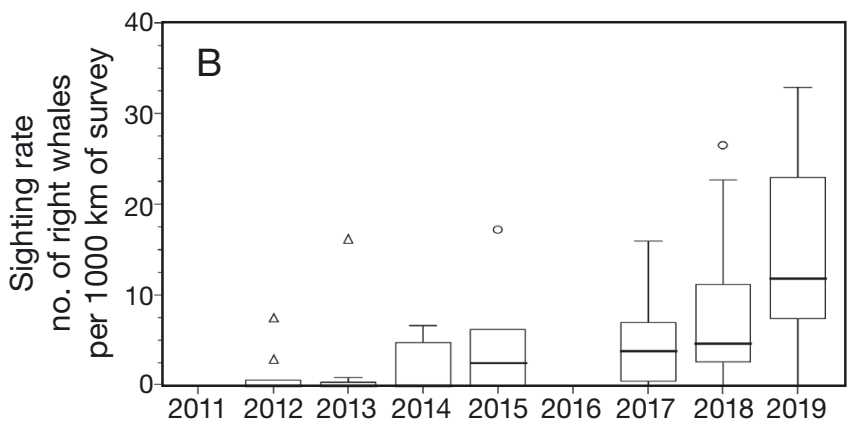

Fig. 3. (A) Mann-Whitney $U$-test comparisons and (B) central tendency and variability of sighting rates of right whales. No right whale sightings were reported in 2011, and no field effort was conducted in 2016 in Dataset 1 (sightings and survey effort collected during aerial surveys conducted by the New England Aquarium). The solid line drawn across each box represents the median sighting rate of that year. The lower boundary is the $25^{\text {th }}$ percentile, and the upper boundary is the $75^{\text {th }}$ percentile of a box. Lines on the top and bottom of each box represent the largest and smallest frequency sighting rates, respectively, excluding outliers (o) and extreme values $(\Delta) .{ }^{*} \mathrm{p}<0.05$
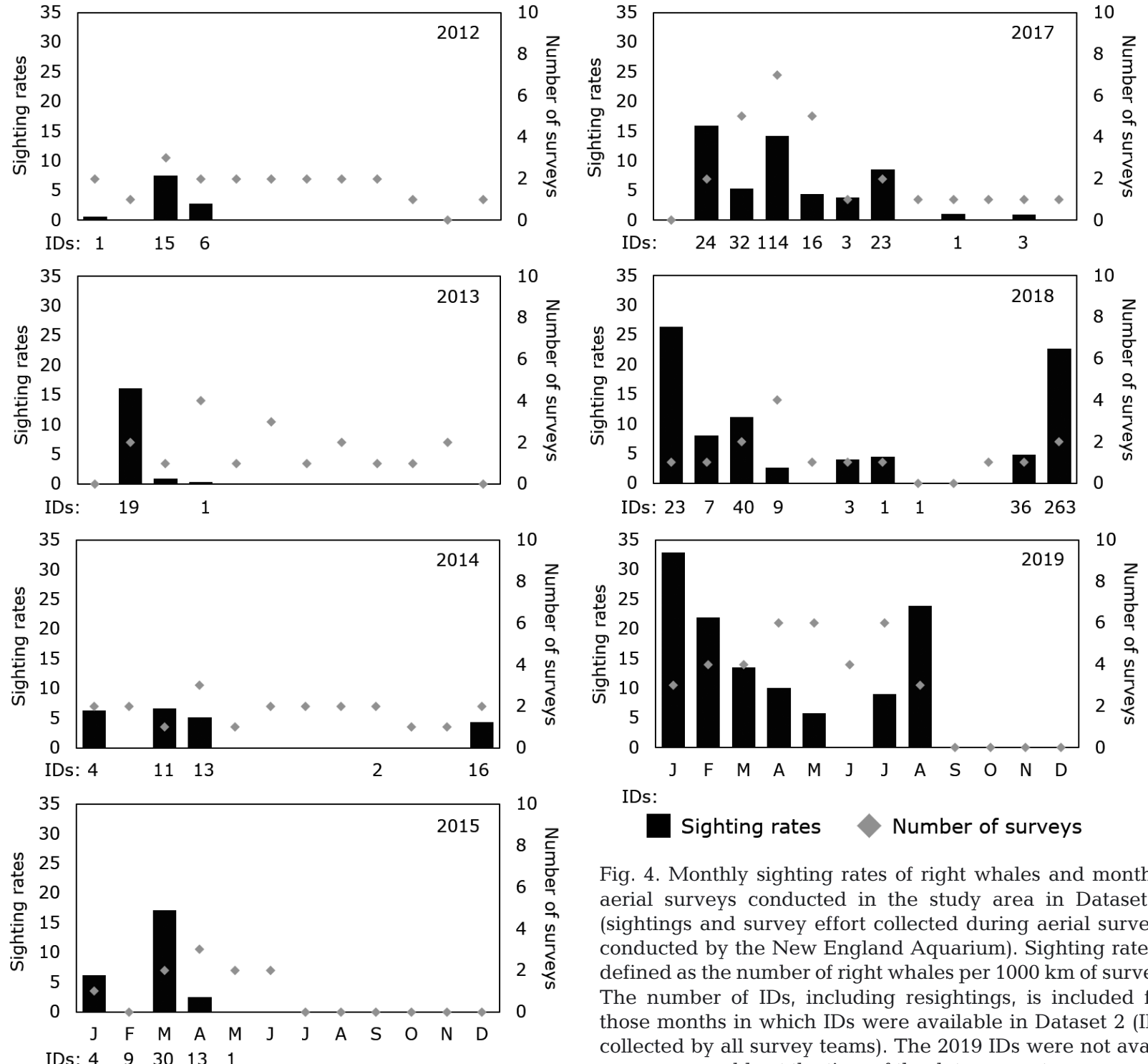

IDs:

\section{Sighting rates Number of surveys}

Fig. 4. Monthly sighting rates of right whales and monthly aerial surveys conducted in the study area in Dataset 1 (sightings and survey effort collected during aerial surveys conducted by the New England Aquarium). Sighting rate is defined as the number of right whales per $1000 \mathrm{~km}$ of survey. The number of IDs, including resightings, is included for those months in which IDs were available in Dataset 2 (IDs collected by all survey teams). The 2019 IDs were not available at the time of the data request 
energy lease sites. In the 2011-2015 winters, right whale sightings increased in the study area and were more concentrated in the northeastern wind energy areas and the southern portion of Nantucket Shoals (Fig. 5A). However, in the 2017-2019 winters, the sightings spanned to the southeastern portion of the shoals (Fig. 5B). In the spring, right whale distribution shifted to the west in both study periods, although in the early years, their distribution was further south of Nantucket (Fig. 5C,D). Summer sightings were only recorded during the 2017-2019 period, with right whales sighted in nearshore waters off Nantucket and along Nantucket Shoals (Fig. 5E).

\subsubsection{Demographics}

The ratio of adults to juveniles in SNE was the same as in the population as a whole during the study. Adult whales were observed significantly more than juveniles, with an annual mean of $70 \%$ adults and $30 \%$ juveniles. The adult:juvenile ratio was significantly different from year to year $\left(G=20.61, \chi^{2} \mathrm{df}=6\right.$, $\mathrm{p}<0.002$ ), but the annual ratios were not significantly different from the yearly population age ratios (Table 3), indicating that the age ratio of the whales visiting the study area followed the age ratio of the population. Sex was confirmed for $93 \%$ of the identifi-
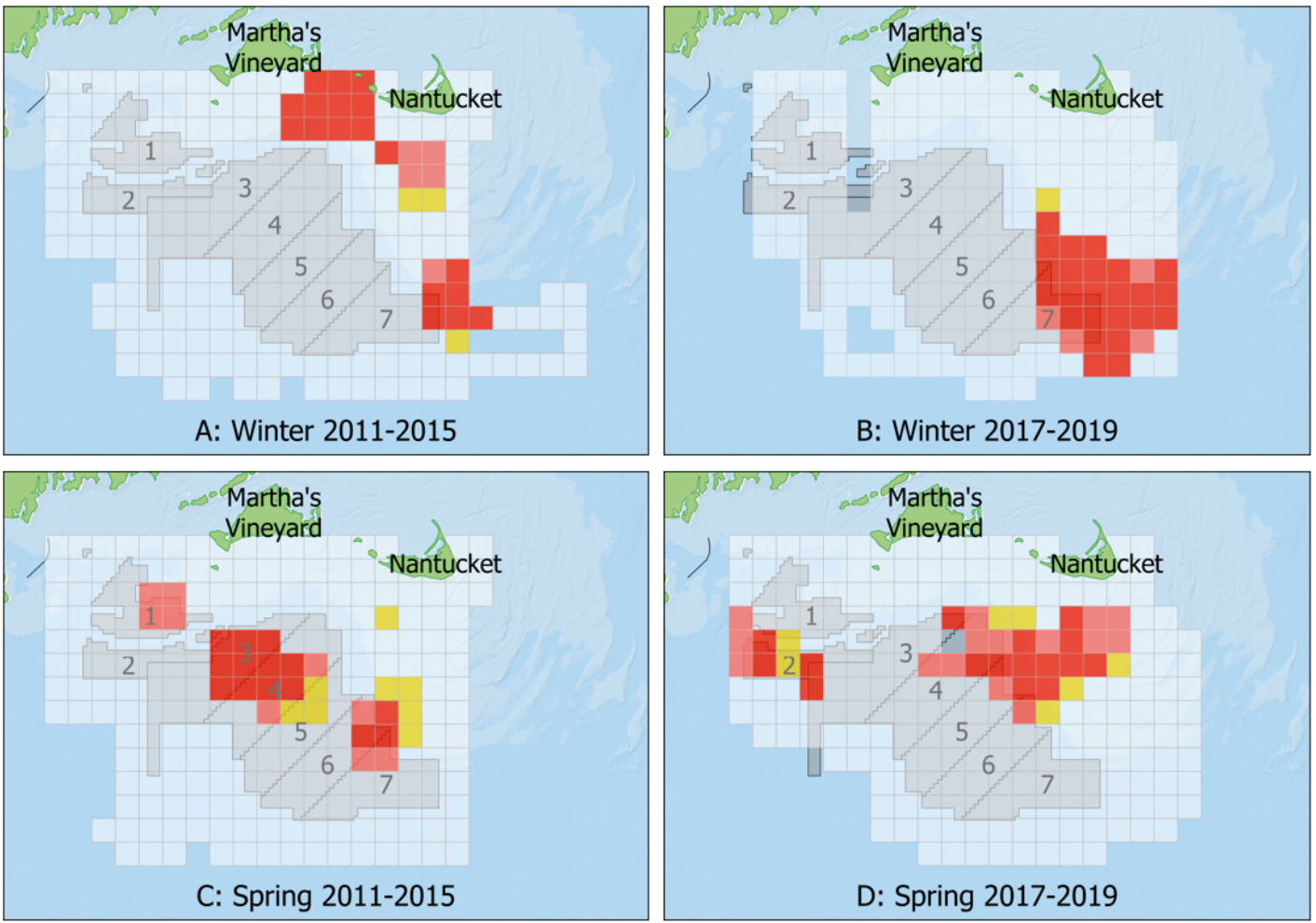

$0 \quad 1020304050 \mathrm{~km}$
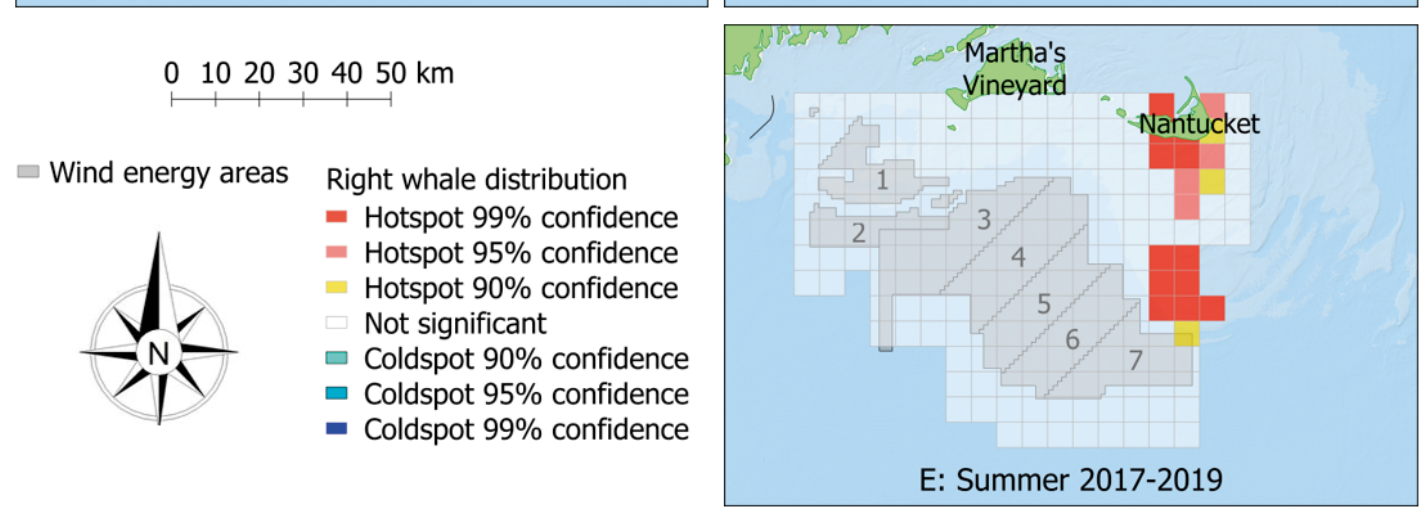

Fig. 5. Hotspot analysis of right whale seasonal distribution in the study area (A,C: 2011-2015; B,D,E: 2017-2019), with hotspots based on significantly higher values than surrounding areas. No coldspots were identified. Wind energy area lease zones are identified by numbers. Additional details of the study area are shown in Fig. 1 
Table 3. Annual numbers of unique adult, juvenile, male, and female right whales sighted in southern New England (SNE), and statistical results of age ratio and sex ratio comparisons to the population ratios (NARWC 2020) using a G-test of goodness of fit with Bonferroni corrected p-values. Annual total numbers of whales of different age and gender classes are not equal because demographic parameters were not always known for all individuals

\begin{tabular}{|c|c|c|c|c|c|c|c|c|}
\hline \multirow[t]{2}{*}{ Year } & \multirow[t]{2}{*}{ Adult } & \multirow[t]{2}{*}{ Juvenile } & \multicolumn{2}{|c|}{$\begin{array}{c}\text { SNE vs. population } \\
\text { age ratios }\end{array}$} & \multirow[t]{2}{*}{ Male } & \multirow[t]{2}{*}{ Female } & \multicolumn{2}{|c|}{$\begin{array}{l}\text { SNE vs. population } \\
\text { sex ratios }\end{array}$} \\
\hline & & & $G$-test (df) & $\mathrm{p}$ & & & $G$-test (df) & $\mathrm{p}$ \\
\hline 2011 & 28 & 20 & 1.96 (1) & 1.00 & 26 & 24 & $0.82(1)$ & 1.00 \\
\hline 2012 & 11 & 8 & 2.21 (1) & 1.00 & 12 & 7 & 0.18 (1) & 1.00 \\
\hline 2013 & 11 & 8 & 2.45 (1) & 1.00 & 10 & 8 & 0.06 (1) & 1.00 \\
\hline 2014 & 24 & 18 & 2.62 (1) & 0.21 & 26 & 17 & 0.08 (1) & 1.00 \\
\hline 2015 & 30 & 18 & 2.89 (1) & 0.49 & 29 & 20 & 0.02 (1) & 1.00 \\
\hline 2017 & 81 & 34 & 3.64 (1) & 0.28 & 66 & 49 & 0.04 (1) & 1.00 \\
\hline 2018 & 156 & 38 & $5.00(1)$ & 1.00 & 117 & 72 & $1.00(1)$ & 1.00 \\
\hline
\end{tabular}

able right whale individuals. Of these, 181 were males and 125 were females. The sex ratios did not vary significantly from year to year $(G=2.04, \mathrm{df}=6, \mathrm{p}=0.92)$. The mean annual percentage of males and females was 57 and $39 \%$, respectively. The observed sex ratio and the population sex ratio did not vary significantly (Table 3 ).

Both reproductive females and conceptive females were seen in the study area. Forty-five of the 108 reproductively active females ( $42 \%$ ) known to be alive during the study were sighted in SNE, and 17 were resighted in multiple years. The overall yearly proportions of reproductively active females varied from 0.25 to $0.57(0.41 \pm 0.05)$. In the case of conceptive females, only 4 females were identified in 4 years (2011, 2012, 2017, 2018), and their yearly proportion varied from 0 to 0.14 $(0.03 \pm 0.02)$. Except for 1 conceptive female which was sighted twice, the others were sighted only once in the study area during their conception period. The genetic information of known fathers was only available for 2011-2013. Of the 13 known fathers, only 2 were sighted (once) in SNE but not during the conceptive period.

Dependent calf sightings were uncommon in SNE, and only descriptive statistics are provided. A total of 89 right whale calves were born in the population between 2011 and 2019, but only 6 different calves (inferred by the presence of known mothers) were recorded during the study in SNE (4 in 2011, 1 in 2015, 1 in 2019). Three calves were sighted twice in the same year.

\subsubsection{Residence}

Individual sighting frequency over the study period varied between 1 and $10 \mathrm{~d}$, suggesting different degrees of residency (Fig. 6). Most right whales $(62 \%, \mathrm{n}=202)$ were sighted more than once over the course of the study, and $42 \%$ of those whales were sighted in between 2 and 6 years $(2 \pm 0.05$ years) (Fig. 6). One whale was sighted nearly every year except in 2013. Within a season, 147 whales were sighted multiple
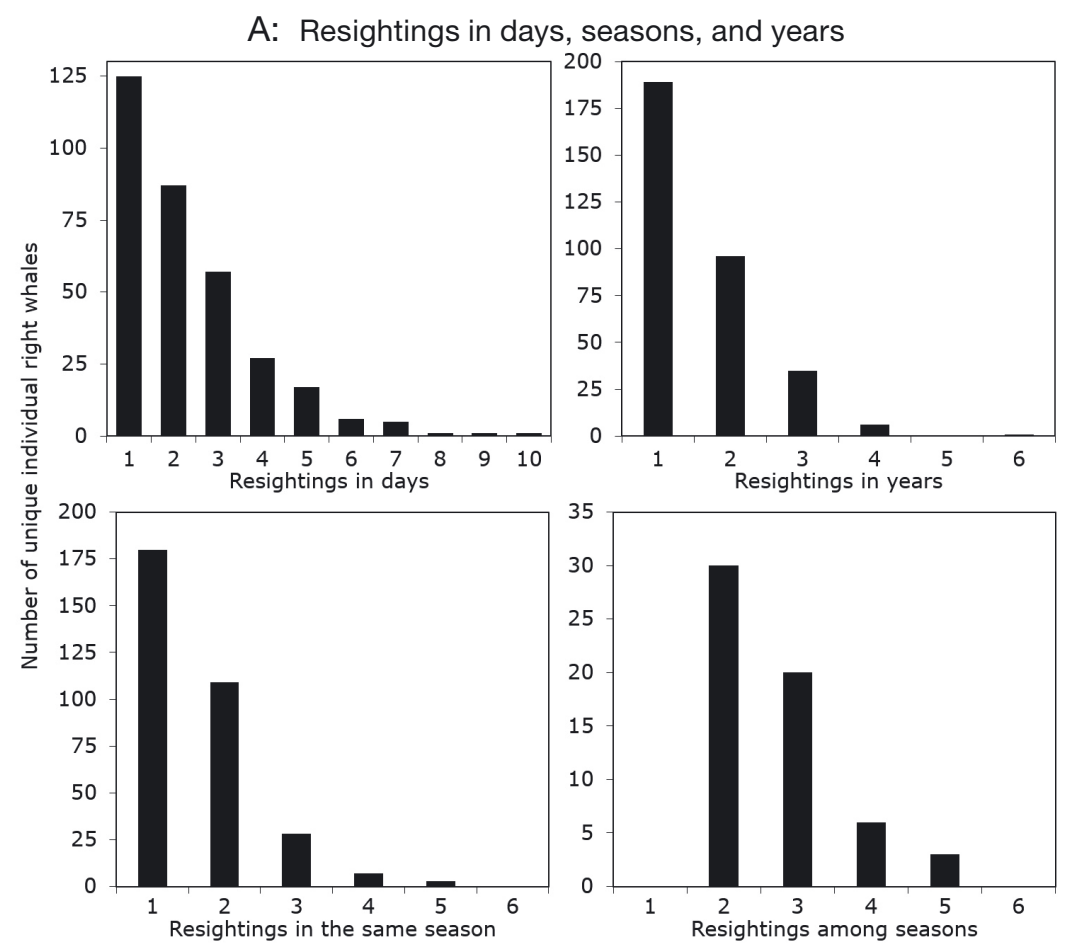

B: Unique IDs and resightings by year

\begin{tabular}{|lccccccc|}
\hline Parameter & 2011 & 2012 & 2013 & 2014 & 2015 & 2017 & 2018 \\
\hline Unique IDs & 53 & 22 & 20 & 43 & 53 & 122 & 202 \\
Resightings in the same season & 12 & 0 & 0 & 3 & 2 & 43 & 87 \\
Resightings among seasons & 0 & 0 & 0 & 0 & 2 & 13 & 44 \\
\hline
\end{tabular}

Fig. 6. Different resighting patterns of uniquely identified right whales at different time scales including (A) during the same season and among seasons and (B) by year in southern New England between 2011 and 2018. No field effort was conducted in 2016 
times ( $\leq 5)$, and 59 whales were sighted several times $(\leq 3)$ in different seasons of the same year. Summer and fall sightings were only common in recent years, and 14 individuals were sighted more than once during this period. Whales resighted the most times included individuals of both sexes as well as adults and juveniles, although the 3 most sighted animals were all males ( 2 adults and 1 juvenile sighted 8-10 times).

Model F (emigration + reimmigration) was the best-fit model to describe the residency of the right whale population in the study area (Table $1 \mathrm{~b}$ ) from December to May, indicating that whales enter, leave, and reenter the study area during this period. In the early years, the model indicated that, on average, $54 \pm 31$ whales were in the study area at any one time during those months and that an individual remained there for an average period of $9 \pm 7 \mathrm{~d}$ (Table 4). However, in recent years, the number of whales estimated to be in the study area during December to May was $65 \pm 18$ right whales, and the residency for both sexes was approximately $13 \pm 12 \mathrm{~d}$ (Table 4). However, these results need to be taken with caution, as bootstrap estimates of the SEs around the estimates were in some cases 1.5 times the mean. Model C (emigration + reimmigration) was also the best fit to explain the emigration rate and proportion of females and males in the study area (Table 1). This model indicated that the emigration rate of females is about 5 times higher than that of males and that $23 \%$ of the population could be present in the study area from December to May.

\subsubsection{Movements}

The transition probabilities of individual whales varied throughout the study. In the winter and spring, the probability of any right whale emigrating from the study area was 3 times higher in 2011-2015 than in 2017-2018 (Table 5). In the early winters, the Gulf of Maine and Cape Cod Bay were the top-ranking destinations for right whales sighted in $\mathrm{SNE}$, with transition probabilities ranging from 0.21 to 0.30 (Table 5). In the same period, the Gulf of Maine, Cape Cod Bay, and the Great South Channel-Georges Bank were the most likely destinations along the US coast for all emigrating right whales (Table 5). However, in recent winters, the Great South ChannelGeorges Bank (destination probability, $P i=0.45$ ) and SNE $(P i=0.47)$ ranked high among the most likely destinations for right whales within the USA. In the spring, other areas were more visited. During the 2011-2015 spring, the South (New York-Florida) was the top-ranking destination for right whales emigrating from SNE, as well as other regions within the USA, but whales sighted in the SNE region also had a high probability of staying in the study area (0.70). In the 2017-2018 spring, the probability of right whales traveling to the South changed from 0.69 to 0.30 (Table 5), while Cape Cod Bay $(P i=0.55)$, SNE ( $P i=$ $0.49)$, and the Gulf of Maine (Pi=0.44) ranked highly as destinations. In recent summers, SNE and the Gulf of St. Lawrence were the high-ranking destinations (Table 5).

Sighting histories of a small percentage of right whales ( $\mathrm{n}=14,<5 \%$ ) identified in the study area showed movement back and forth between areas, mainly between SNE and Cape Cod Bay and between SNE and the South (New York). Eleven right whales, including 6 adult males, 3 adult females, and 2 juvenile males, were first sighted in Cape Cod Bay ( $\geq 1$ time), then once in SNE, and then again in Cape Cod Bay ( $\geq 1$ time). The number of days between sightings of a whale at these 2 areas ranged from 3 to $42 \mathrm{~d}$. The other 3 right whales were first sighted in $\mathrm{SNE}$, then in either Cape Cod Bay or the South (New

Table 4. Parameters of the model(s) \pm standard error that best fit the lag identification rates of all right whales including females and males in southern New England, December-May, during the study periods 2011-2015 and 2017-2018. Time in/out: time spent in/outside of the study area; (-) not applicable

\begin{tabular}{|c|c|c|c|c|c|c|}
\hline \multirow{2}{*}{ Model type and parameters } & \multicolumn{3}{|c|}{$-2011-2015$} & \multicolumn{3}{|c|}{$-2017-2018$} \\
\hline & All & Female & Male & All & Female & Male \\
\hline \multicolumn{7}{|l|}{ F: Emigration + reimmigration } \\
\hline Number of visitors & $54 \pm 31$ & $14 \pm 7$ & $18 \pm 33$ & $65 \pm 18$ & $28 \pm 13$ & $36 \pm 9$ \\
\hline Time in $(d)$ & $9 \pm 7$ & $4 \pm 3$ & $5 \pm 43$ & $13 \pm 12$ & $15 \pm 24$ & $18 \pm 51$ \\
\hline Time out $(\mathrm{d})$ & $63 \pm 42$ & $21 \pm 24$ & $41 \pm 163$ & $50 \pm 46$ & $64 \pm 70$ & $97 \pm 136$ \\
\hline \multicolumn{7}{|l|}{ C: Emigration + reimmigration } \\
\hline Emigration rate & - & - & $0.25 \pm 2.06$ & $0.10 \pm 0.91$ & $0.33 \pm 1.39$ & $0.06 \pm 1.53$ \\
\hline $\begin{array}{l}\text { Proportion of population in } \\
\text { study area at any time }\end{array}$ & - & - & $0.09 \pm 0.0001$ & $0.23 \pm 0.001$ & $0.14 \pm 0.0001$ & $0.17 \pm 0.0002$ \\
\hline
\end{tabular}


Table 5. Seasonal transition probabilities of right whales moving between southern New England (SNE) and other right whale areas along the North Atlantic. Destination probabilities (columns) are shown as $P i$, and origin probabilities (rows) are shown as $P e$, including the probability of staying within the original region of the sighting (diagonal). There were no data for summer destination 2011-2015; GSL: Gulf of St. Lawrence; BOF: Bay of Fundy; GOM: Gulf of Maine; CCB: Cape Cod Bay; GSB: Great South Channel-Georges Bank; SOU: South (New York-Florida)

\begin{tabular}{|c|c|c|c|c|c|c|c|c|c|c|c|c|c|c|c|c|c|}
\hline \multirow[b]{2}{*}{ Origin } & \multicolumn{8}{|c|}{$\begin{array}{c}2011-2015 \\
\text { Winter destination }\end{array}$} & & \multicolumn{8}{|c|}{$\begin{array}{c}2017-2018 \\
\text { Winter destination }\end{array}$} \\
\hline & GSL $^{a}$ & $\mathrm{BOF}^{\mathrm{a}}$ & GOM & CCB & SNE & GSB & SOU & $P e$ & & $\mathrm{GSL}^{\mathrm{b}}$ & $\mathrm{BOF}^{\mathrm{a}}$ & GOM & $\mathrm{CCB}$ & SNE & GSB & SOU & $P e$ \\
\hline \multicolumn{18}{|l|}{ GSL } \\
\hline \multicolumn{18}{|l|}{ BOF } \\
\hline GOM & & & 0.80 & 0.03 & 0.08 & 0.04 & 0.04 & 0.20 & & & & & & & & & \\
\hline CCB & & & $<0.01$ & 0.30 & 0.16 & 0.53 & $<0.01$ & 0.70 & & & & & 0.69 & 0.04 & 0.15 & 0.12 & 0.31 \\
\hline SNE & & & 0.21 & 0.29 & 0.33 & 0.11 & 0.06 & 0.67 & & & & & 0.02 & 0.80 & 0.18 & $<0.01$ & 0.20 \\
\hline GSB & & & 0.16 & 0.14 & 0.11 & 0.59 & 0.08 & 0.49 & & & & & 0.12 & 0.28 & 0.61 & $<0.01$ & 0.40 \\
\hline SOU & & & 0.08 & 0.03 & 0.001 & 0.01 & 0.08 & 0.13 & & & & & 0.13 & 0.15 & 0.13 & 0.60 & 0.40 \\
\hline \multirow[t]{2}{*}{$P i$} & & & 0.45 & 0.50 & 0.36 & 0.68 & 0.17 & & & & & & 0.27 & 0.47 & 0.45 & 0.12 & \\
\hline & \multicolumn{8}{|c|}{ Spring destination } & & \multicolumn{8}{|c|}{ Spring destination } \\
\hline Origin & $\mathrm{GSL}^{\mathrm{a}}$ & $\mathrm{BOF}^{\mathrm{a}}$ & GOM & $\mathrm{CCB}$ & SNE & GSB & SOU & $P e$ & & $\mathrm{GSL}^{\mathrm{b}}$ & $\mathrm{BOF}^{\mathrm{a}}$ & GOM & $\mathrm{CCB}$ & SNE & GSB & SOU & $P e$ \\
\hline \multicolumn{18}{|l|}{ GSL } \\
\hline \multicolumn{18}{|l|}{$\mathrm{BOF}$} \\
\hline GOM & & & 0.34 & 0.14 & 0.14 & 0.06 & 0.32 & 0.66 & & & & 0.19 & 0.44 & 0.09 & 0.10 & 0.17 & 0.81 \\
\hline $\mathrm{CCB}$ & & & 0.04 & 0.82 & 0.03 & 0.06 & 0.04 & 0.18 & & & & 0.24 & 0.73 & $<0.01$ & 0.02 & $<0.01$ & 0.27 \\
\hline SNE & & & $<0.01$ & 0.07 & 0.72 & 0.08 & 0.14 & 0.29 & & & & $<0.01$ & 0.04 & 0.89 & 0.01 & 0.06 & 0.11 \\
\hline GSB & & & 0.14 & 0.09 & 0.05 & 0.55 & 0.19 & 0.47 & & & & 0.09 & 0.03 & 0.17 & 0.64 & 0.07 & 0.36 \\
\hline SOU & & & 0.07 & 0.16 & 0.16 & 0.12 & 0.41 & 0.51 & & & & 0.10 & 0.04 & 0.23 & 0.06 & 0.58 & 0.42 \\
\hline \multirow[t]{11}{*}{$P i$} & & & 0.24 & 0.46 & 0.39 & 0.32 & 0.69 & & & & & 0.44 & 0.55 & 0.49 & 0.19 & 0.30 & \\
\hline & & & & & & & & & & \multicolumn{8}{|c|}{ Summer destination } \\
\hline & & & & & & & & & Origin & GSL & $\mathrm{BOF}$ & $\mathrm{GOM}^{\mathrm{b}}$ & $\mathrm{CCB}^{\mathrm{a}}$ & SNE & $\mathrm{GSB}^{\mathrm{b}}$ & $\mathrm{SOU}^{\mathrm{a}}$ & $P e$ \\
\hline & & & & & & & & & GSL & 0.88 & $<0.01$ & & & 0.12 & & & 0.12 \\
\hline & & & & & & & & & $\mathrm{BOF}$ & 0.09 & 0.72 & & & 0.19 & & & 0.28 \\
\hline & & & & & & & & & GOM & & & & & & & & \\
\hline & & & & & & & & & $\mathrm{CCB}$ & & & & & & & & \\
\hline & & & & & & & & & SNE & 0.12 & 0.05 & & & 0.82 & & & 0.87 \\
\hline & & & & & & & & & GSB & & & & & & & & \\
\hline & & & & & & & & & SOU & & & & & & & & \\
\hline & & & & & & & & & $P i$ & 0.21 & 0.05 & & & 0.31 & & & \\
\hline
\end{tabular}

York), and then again in SNE (1 adult male, 1 juvenile male, 1 adult female). The gap between sightings of an individual moving between these areas varied between 19 and $78 \mathrm{~d}$. The gap in resighting times is likely more of a reflection of survey effort than of the whales' movements among locations.

\section{DISCUSSION}

This $8 \mathrm{yr}$ analysis of sightings revealed that right whales have become more common in SNE waters, with sightings now documented in nearly every month of the year. Sighting rates were highest in the span from winter through early spring and sometimes even during the summer months (e.g. August 2019).
Our effort included off-transect periods such as circling, cross-legs, and transits (Leiter et al. 2017). Thus, sighting rates estimated by this analysis should be compared only to studies using a similar analytical approach. Close to a quarter of the population may be in this area at any given time between December and May, and the annual percentage of right whales identified varied between 4 and $53 \%(13 \pm 4 \%)$ of the minimum right whale population. SNE is also an important habitat used by all demographic groups because the age and sex ratios are similar to those in the overall species population, and the estimated residency duration for females and males tripled during the study period. The apparent increased use of this habitat could be related to an increased field effort in recent years, which resulted in a higher number of 
identifications, and/or to dramatic climate-driven ecosystem changes that have occurred in the past decade (Record et al. 2019). Migratory species such as right whales are particularly affected by climate change because they rely on highly productive seasonal habitats (Robinson et al. 2009).

Right whales exhibit partial migration (Gowan et al. 2019), a term used to describe a species in which a proportion of a population stays resident in a habitat(s) and another proportion migrates to another habitat(s) (Chapman et al. 2011). It is a widespread phenomenon in invertebrates (Menz et al. 2019), fish (Chapman et al. 2012), birds (Lundberg 1988), and mammals (Cagnacci et al. 2011, Martin et al. 2018, Berg et al. 2019). In the case of right whales, all demographic groups have the potential to migrate to the wintering grounds off the southeastern USA, but the migration appears to be condition dependent and varies across demographic groups and years. Females may overwinter in the feeding areas in the north and skip the breeding grounds in the south in the years immediately preceding and following calving to increase their energy stores for future reproduction (Gowan et al. 2019). On the other hand, juveniles and adult males may travel to the southern wintering grounds following years of higher prey availability in a northern fall feeding ground (Gowan et al. 2019).

The mixture of movement patterns within the population and the geographical location of SNE suggests that the area could be a feeding location for whales that stay in the mid-Atlantic and north during the winter-spring months and a stopover site for whales migrating to and from the calving grounds. For example, a female right whale initially tagged off the coast of Virginia in March 2021 traveled for $13 \mathrm{~d}$ to SNE, where she stayed for $3 \mathrm{~d}$ before traveling north towards Cape Cod Bay (D. Engelhaupt pers. comm.). Because of the complex movements displayed by the species, our use of the term residence describes the minimum time a right whale could spend in SNE regardless of the overall movement that the whale exhibited at that time. It does not suggest that right whales overwinter in SNE.

Our findings show that SNE is an important transition region, as the whales that utilized the area moved to and from critical habitats including Cape Cod Bay, the Gulf of Maine, and the Great South Channel-Georges Bank, and in the summer, many traveled on to the Gulf of St. Lawrence. Florida and Georgia were more frequent destinations when calving rates were higher (Pace et al. 2017) in the early study period, but the recent low transition rates could be due to a lack of births in 2018 or changes in survey efforts and right whale movements. The sightings of SNE whales in Canadian waters and multiple USA locations, including the mid-Atlantic, emphasize the need for protecting coastal areas that serve as migratory corridors.

Right whales may utilize SNE as a feeding ground more often than as a social or mating ground, although behaviors linked to both activities have been observed in the area. Feeding was recorded on more occasions than socializing, and it was observed in all seasons, whereas surface active groups were observed mainly in the winter and spring. Preliminary results of oceanographic surveys conducted in waters near right whale sightings suggest that their diet includes multiple zooplankton species including Calanus finmarchius and Centropages sp. (QuintanaRizzo et al. 2018). Evidence of feeding throughout the seasons provides support for the extension of US feeding critical habitats into SNE waters.

Almost $50 \%$ of reproductive females utilized this area within the study period, which is an important consideration for the species' conservation since the overall population has declined significantly (Pace et al. 2017, Corkeron et al. 2018). Conceptive females were not often seen, and their proportional presence was not as high as in the inferred mating ground identified by Cole et al. (2013) over a decade ago. However, large numbers of conceptive females are not required for mating to occur because mating groups often consist of many males and 1 female (Kraus \& Hatch 2001). Few calves were seen in SNE, in contrast to Cape Cod Bay, where calf sightings have increased and up to $40 \%$ of the calves born in a given year can be sighted (Mayo et al. 2018).

Individual right whales were sighted more frequently in Cape Cod Bay than in SNE in the winter and spring, and some whales move back and forth between the feeding habitats. The relative importance of the 2 areas for the whales is difficult to assess since differences in the frequency of apparent habitat use are likely confounded by differences in survey coverage. Cape Cod Bay is a much smaller area surrounded by land on 3 sides, and comprehensive surveys are conducted weekly during the primary period of right whale presence there between January and April, whereas SNE is an extensive oceanic area, and surveys were conducted only a few times per month throughout the year.

The year-round productivity of Nantucket Shoals (PCCS 2005) may influence the presence of right whales, even in low numbers. Indeed, the shoals appear to be a hotspot for right whales throughout most of the year. The shoals extend eastward and 
southeastward of Nantucket Island (Fig. 1B; Freire et al. 2015). The shoals and Nantucket Sound form one of the largest tidal dissipation areas in the Gulf of Maine and New England regions (Chen et al. 2018). The tidal dissipation creates a local tidal pump that serves as the primary driver for the relatively high phytoplankton biomass in the shoals' shallow dunelike regions all year (Hu et al. 2008, Saba et al. 2015), which presumably correlates to zooplankton prey for right whales.

In recent years, right whale sightings in SNE waters in winter were concentrated in the eastern portion of the area, near Nantucket Shoals, and in and near Zones 6 and 7 of the Massachusetts wind energy area. In the spring, right whale sightings increased in the northern parts of the wind energy areas and shifted generally westward, but their specific locations and extents varied with time. Late spring aggregations of right whales were recently detected outside of the study area, near the Ambrose-Nantucket shipping lanes south of the Massachusetts wind energy areas (Fig. 1B), by NEAq and NEFSC aerial surveys. This demonstrates that right whale aggregations vary in space and time and can be formed in nearby locations from which the whales could easily move to the wind energy areas. In recent summers, right whale sightings increased in the Nantucket coastal and shoal waters, but the observation efforts also became more frequent. Sightings in these Nantucket locations were common in the summer of 2020 and extended into the early fall, as suggested by observations of right whales during the NEFSC surveys (NEFSC unpubl. data). The 2019 and 2020 identifications were unavailable at the time of our data request, but preliminary results suggest that a high number of juveniles were present in SNE waters at this time in contrast to 2017 and 2018 (QuintanaRizzo et al. 2019a,b). Additional data collection over the coming years will reveal whether or not this pattern continues.

The presence of right whales in SNE throughout all seasons is important to determine appropriate management actions. The study area is bracketed by 2 right whale seasonal management areas (SMAs); these are regulatory protection zones along the US east coast in which vessels larger than 300 gross tons must slow to 10 knots or less when transiting (NMFS 2008). To protect aggregations of right whales outside of the SMAs, the National Marine Fisheries Service has voluntary dynamic management areas (DMAs), which are triggered when 3 or more whales are sighted within close proximity to each other. DMAs last for $15 \mathrm{~d}$ from the date of the sighting(s) that trig- gered them (NMFS 2008). It requests that ships avoid DMAs or transit through them at 10 knots or less. A recent assessment of the automatic identification system data of vessel traffic for these DMAs indicates very low mariner cooperation with speed reduction requests (NMFS 2020). In 2017 and 2018, the annual number of DMAs doubled from the annual average of 3 DMAs in the 2011-2016 period. In 2019, the number of triggered or extended DMAs reached a peak, with an active DMA in every month except October (NEFSC unpubl. data).

The presence of right whales in SNE during all seasons is an important consideration for the planning and execution of offshore wind development. The historical seasonal migratory pattern should not be used alone to determine time-sensitive actions in this habitat. Monitoring and mitigation plans should include protocols for the likely presence of right whales throughout the year (Whitt et al. 2013). Their increasing summer and fall presence deserves special attention since this will overlap with the current schedule for pile driving for turbine foundations in the next few years, the phase of construction considered to have the greatest acoustic impact (Madsen et al. 2006, Thompson et al. 2010), which could potentially affect right whale behavior. This timing was originally selected based on the observed seasonality of right whales in SNE (Leiter et al. 2017), but our findings show that their seasonal occurrence has changed. Management and mitigation procedures should be adapted and reevaluated continually in relation to right whales' use of the area.

Although the effects of offshore wind energy development on right whales are unknown, it has been reported that baleen whales avoid impulsive sounds with noise levels similar to those of piledriving activities (Madsen et al. 2006, Stone \& Tasker 2006). Migrating baleen whales such as the bowhead whale Balaena mysticetus, a distant cousin of the right whale, avoided airguns at approximately $20 \mathrm{~km}$ (Richardson et al. 1999). Minke whales rapidly flee from military sonar exposures (Dolman \& Simmonds 2010), and their numbers decline during naval activity (Parsons et al. 2000). The effects of noise associated with vessel traffic during the construction and maintenance of the wind turbines are also unclear, but right whales have not previously exhibited behavioral responses to approaching vessels (Nowacek et al. 2004). However, analyses of right whale fecal samples suggest that noise from large commercial vessels increases their stress levels (Rolland et al. 2012). Although right whales may be able to vocally adapt to increased low-frequency noise to some 
degree through a shift in vocalization frequency and duration (Parks et al. 2007b, 2009, 2011), the above findings suggest that the whales could potentially be negatively affected by disturbances from sound and noise related to wind energy development. Increased vessel traffic associated with the construction and maintenance of turbines also increases the risk of whales being struck.

Implementing mitigation measures by all leaseholding companies will be crucial. The first leasing company to start pile-driving activities in the Massachusetts wind energy area has agreed to implement enhanced mitigation procedures to detect and protect right whales from early winter to mid-May, to avoid pile driving from January to April, and to maintain a comprehensive monitoring effort during the other months of the year that construction might take place (Vineyard Wind, NGO Agreement 2019). Mitigation procedures will include using real-time acoustic monitoring, having certified protected species observers on a vessel stationed at the pile-driving site, and using vessel surveys during daylight hours within a $10 \mathrm{~km}$ range of the construction site (Vineyard Wind, NGO Agreement 2019). However, conservation and management efforts will need to identify specific indicators of potential impacts to reduce uncertainty, especially as the offshore wind energy industry grows and expands (Hill \& Arnold 2012, Madsen et al. 2015). Abundance and distribution studies will not be enough to understand potential changes in right whale patterns considering the largescale shifts that the species is experiencing. Examples of indicators exist in studies conducted in Europe (Köppel 2017, Bispo et al. 2019), where wind energy development has a long history. Studies designed to examine the consequences of acoustic exposure to construction noise are urgently needed. The area of the potential effect of acoustic exposure can extend far beyond the immediate vicinity of the proposed development and cause behavioral disturbances in animals in a large area (Thomsen et al. 2006). Work is also needed to determine if wind farms alter the habitat's physical and oceanographic characteristics (Wilhelmsson et al. 2006, Broström 2008, Paskyabi \& Fer 2012, Paskyabi 2015, Carpenter et al. 2016). This may have cascading impacts on the food chain in the region, which could potentially displace right whales to other areas. Estimating the potential impacts of offshore wind farms on right whales or their causeand-effect relationships will be challenging at a time in which whale numbers and distributions are changing, but this is necessary to inform appropriate strategies for future wind energy development.
Acknowledgements. Funding for survey effort was provided by the Bureau of Ocean Energy Management under Cooperative Agreement M17AC00002 and the Massachusetts Clean Energy Center (MassCEC). NEAq surveys were conducted under NOAA permits no. 14233 (2011-2015) and no. 19674 (2017-2019) issued to Scott D. Kraus. NOAA surveys were conducted under research permits no. 17355 June 2013-June 2018 and no. 21371 after June 2018. NOAA Fisheries funded the publication of this paper. The work includes data collected and processed by multiple institutions - our sincere thanks to the contributors of the North Atlantic Right Whale Consortium and to the many observers who collected and processed sighting data at different organizations. At NEAq, we acknowledge the work of A. Bostwick, J. Anderson, J. Taylor, S. Mussoline, K. Stone, and T. Montgomery. At NEFSC, we recognize the work of A. Ogilvie, J. Gatzke, K. Vale, C. Accardo, and K. Slivka. At CCS, we thank A. James, L. Ganley, and P. Hughes. Surveys were possible with the coordination of Avwatch, in particular C. Kluckhuhn, T. Laue, R. Jackson, B. Strakele, M. Cortese, and D. Heikkila. We thank D. LeRoi for his technical assistance. H. Pettis, P. Hamilton, and R. Kenney provided helpful support during the data request. R. Kenney calculated the survey effort of the aerial teams working in SNE. M. Zani was instrumental in identifications and catalog work completed in 2011-2015. J. Roberts, C. Orphanides, and an anonymous reviewer provided very useful comments to improve the manuscript. E.Q.R. thanks N. Bolgen for his support; D. Engelhaupt for sharing information on the movements of a tagged right whale; $\mathrm{H}$. Whitehead for the valuable discussions on the movement and residence models even in the middle of the pandemic; and S. Brillant, A. Vanderlaan, and M. Smithson for insightful discussions in the early stages of the manuscript. This work is dedicated to the North Atlantic right whale.

\section{LITERATURE CITED}

Baracho-Neto C, Neto E, Rossi-Santos M, Wedekin L, Neves M, Lima F, Faria D (2012) Site fidelity and residence times of humpback whales (Megaptera novaeangliae) on the Brazilian coast. J Mar Biol Assoc UK 92:1783-1791

* Berg J, Hebblewhite M, Clair CC, Merrill E (2019) Prevalence and mechanisms of partial migration in ungulates. Front Ecol Evol 7:325

Bispo R, Bernadino J, Coelho H, Costa JL (eds) (2019) Wind energy and wildlife impacts. Balancing energy sustainability with wildlife conservation. Springer, Cham

Brillant SW, Vanderlaan ASM, Rangeley RW, Taggart CT (2015) Quantitative estimates of the movement and distribution of North Atlantic right whales along the northeast coast of North America. Endang Species Res 27: 141-154

Broström G (2008) On the influence of large wind farms on the upper ocean circulation. J Mar Syst 74:585-591

Brown MW, Fenton D, Smedbol K, Merriman C, RobichaudLeblanc K, Conway JD (2009) Recovery strategy for the North Atlantic right whale (Eubalaena glacialis) in Atlantic Canadian waters. Species at Risk Act recovery strategy series. Fisheries and Oceans Canada, Ottawa

Cagnacci F, Focardi S, Heurich M, Stache A and others (2011) Partial migration in roe deer: migratory and resident tactics are end points of a behavioural gradient determined by ecological factors. Oikos 120:1790-1802 Carpenter JR, Merckelbach L, Callies U, Clark S, Gaslikova 
L, Baschek B (2016) Potential impacts of offshore wind farms on North Sea stratification. PLOS ONE 11:e0160830

Chabanne DBH, Finn H, Bejder L (2017) Identifying the relevant local population for environmental impact assessments of mobile marine fauna. Front Mar Sci148

Chapman BB, Brönmark C, Nilsson JÅ, Hansson LA (2011) The ecology and evolution of partial migration. Oikos 120:1764-1775

* Chapman BB, Hulthén K, Brodersen J, Nilsson PA, Skov C, Hansson LA, Brönmark C (2012) Partial migration in fishes: causes and consequences. J Fish Biol 81:456-478

* Charif RA, Shiu Y, Muirhead CA, Clark CW, Parks SE, Rice AN (2020) Phenological changes in North Atlantic right whale habitat use in Massachusetts Bay. Glob Change Biol 26:734-745

Chen Z, Curchitser E, Chant R, Kang D (2018) Seasonal variability of the cold pool over the Mid-Atlantic Bight continental shelf. J Geophys Res C Oceans 123:8203-8226

Cole TVN, Hamilton P, Henry AG, Duley P, Pace RM III, White BN, Frasier T (2013) Evidence of a North Atlantic right whale Eubalaena glacialis mating ground. Endang Species Res 21:55-64

* Cooke JG (2020) Eubalaena glacialis. The IUCN Red List of Threatened Species 2020:e.T41712A162001243. https:// dx.doi.org/10.2305/IUCN.UK.2020-2.RLTS.T41712A162 001243.en (accessed 24 Nov 2020)

* Corkeron P, Hamilton P, Bannister J, Best P and others (2018) The recovery of North Atlantic right whales, Eubalaena glacialis, has been constrained by human-caused mortality. R Soc Open Sci 5:180892

Davies KTA, Brillant SW (2019) Mass human-caused mortality spurs federal action to protect endangered North Atlantic right whales in Canada. Mar Policy 104:157-162

*Davies KTA, Vanderlaan ASM, Smedbol RK, Taggart CT (2015) Oceanographic connectivity between right whale critical habitats in Canada and its influence on whale abundance indices during 1987-2009. J Mar Syst 150: 80-90

Davies KTA, Brown MW, Hamilton PK, Knowlton AR, Taggart CT, Vanderlaan ASM (2019) Variation in North Atlantic right whale Eubalaena glacialis occurrence in the Bay of Fundy, Canada, over three decades. Endang Species Res 39:159-171

Davis GE, Baumgartner MF, Bonnell JM, Bell J and others (2017) Long-term passive acoustic recordings track the changing distribution of North Atlantic right whales (Eubalaena glacialis) from 2004 to 2014. Sci Rep 7:13460

Deakos MH, Baker JD, Bejder L (2011) Characteristics of a manta ray Manta alfredi population off Maui, Hawaii, and implications for management. Mar Ecol Prog Ser 429:245-260

* Dinis A, Alves F, Nicolau C, Ribeiro C, Kaufmann M, Cañadas A, Freitas L (2016) Bottlenose dolphin Tursiops truncatus group dynamics, site fidelity, residency and movement patterns in the Madeira Archipelago (NorthEast Atlantic). Afr J Mar Sci 38:151-160

* Dolman S, Simmonds M (2010) Towards best environmental practice for cetacean conservation in developing Scotland's marine renewable energy. Mar Policy 34: 1021-1027

* Firestone J, Lyons SB, Wang C, Corbett JJ (2008) Statistical modeling of North Atlantic right whale migration along the mid-Atlantic region of the eastern seaboard of the United States. Biol Conserv 141:221-232

Fisheries and Oceans Canada (2014) Recovery strategy for the North Atlantic right whale (Eubalaena glacialis) in Atlantic Canadian waters. Species at Risk Act recovery strategy series. Fisheries and Oceans Canada, Ottawa

F Foley HJ, Holt RC, Hardee RE, Nilsson PB and others (2011) Observations of a western North Atlantic right whale (Eubalaena glacialis) birth offshore of the protected southeast US critical habitat. Mar Mamm Sci 27:E234-E240

Frasier TR, Hamilton PK, Brown MW, Conger LA and others (2007) Patterns of male reproductive success in a highly promiscuous whale species: the endangered North Atlantic right whale. Mol Ecol 16:5277-5293

Freire R, Pe'eri S, Madore B, Rzhanov Y, Alexander L, Parrish CE, Lippmann TC (2015) Monitoring near-shore bathymetry using a multi-image satellite-derived bathymetry approach. US Hydrographic Conference 2015

Ganley LC, Brault S, Mayo CA (2019) What we see is not what there is: estimating North Atlantic right whale Eubalaena glacialis local abundance. Endang Species Res 38:101-113

Getis A, Ord JK (1992) The analysis of spatial association by use of distance statistics. Geogr Anal 24:189-206

* Gowan TA, Ortega-Ortiz JG, Hostetler JA, Hamilton PK and others (2019) Temporal and demographic variation in partial migration of the North Atlantic right whale. Sci Rep 9:353

Hamilton PK, Marx MK, Kraus SD (1995) Weaning in North Atlantic right whales. Mar Mamm Sci 11:386-390

Hamilton PK, Knowlton AR, Marx MK (2007) Right whales tell their own stories: the photo-identification catalog. In: Kraus SD, Rolland RM (eds) The urban whale: North Atlantic right whales at the crossroads. Harvard University Press, Cambridge, MA, p 75-104

*Hatch LT, Clark CW, Van Parijs SM, Frankel AS, Ponirakis DW (2012) Quantifying loss of acoustic communication space for right whales in and around a US national marine sanctuary. Conserv Biol 26:983-994

Hill D, Arnold R (2012) Building the evidence base for ecological impact assessment and mitigation. J Appl Ecol 49:6-9

* Hu SD, Townsend W, Chen C, Cowles G, Beardsley RC, Rubao J, Houghton RW (2008) Tidal pumping and nutrient fluxes on Georges Bank: a process-oriented modeling study. J Mar Syst 74:528-544

IWC Int (International Whaling Commission) (2001) Report of the workshop on the comprehensive assessment of right whales: a worldwide comparison. J Cetacean Res Manag 1-35. Available at https://journal.iwc.int/index.php/ jcrm/article/view/270

Kenney RD (2019) The North Atlantic Right Whale Consortium database: a guide for users and contributors, version 6. North Atlantic Right Whale Consortium Ref Doc 2019-02. University of Rhode Island, Narragansett, RI

Khan C, Cole T, Duley P, Henry A, Gatzke J (2011) North Atlantic right whale sighting survey (NARWSS) and right whale sighting advisory system (RWSAS) 2010 results summary. US Dep Commer, Northeast Fish Sci Cent Ref Doc 11-05

Knowlton AR, Kraus SD, Kenney RD (1994) Reproduction in North Atlantic right whales (Eubalaena glacialis). Can J Zool 72:1297-1305

Köppel J (2017) Wind energy and wildlife interactions. Presentations from the CWW2015 conference. Springer, Cham

Kraus SD, Hatch JJ (2001) Mating strategies in the North Atlantic right whale (Eubalaena glacialis). J Cetacean Res Manag Spec Issue 2:237-244 
Kraus SD, Rolland RM (2007) The urban whale syndrome. In: Kraus SD, Rolland RM (eds) The urban whale: North Atlantic right whales at the crossroads. Harvard University Press, Cambridge, MA, p 488-513

Kraus SD, Moore KE, Price CA, Crone MJ, Watkins WA, Winn HE, Prescott JH (1986) The use of photographs to identify individual North Atlantic right whales (Eubalaena glacialis). Rep Int Whal Comm Spec Issue 10:145-151

Kraus SD, Hamilton P, Kenney RD, Knowlton A, Slay CK (2001) Reproductive parameters of the North Atlantic right whale. J Cetacean Res Manag Spec Issue 2:231-236

Kraus SD, Kenney RD, Mayo CA, McLellan WA, Moore MJ, Nowacek DP (2016a) Recent scientific publications cast doubt on North Atlantic right whale future. Front Mar Sci 3:137

Kraus SD, Leiter S, Stone K, Wikgren B and others (2016b) Northeast large pelagic survey collaborative aerial and acoustic surveys for large whales and sea turtles. OCS Study BOEM 2016-054. US Department of the Interior, Bureau of Ocean Energy Management, Sterling, VA

Leiter SM, Stone KM, Thompson JL, Accardo CM and others (2017) North Atlantic right whale Eubalaena glacialis occurrence in offshore wind energy areas near Massachusetts and Rhode Island, USA. Endang Species Res 34: 45-59

Lundberg P (1988) The evolution of partial migration in birds. Trends Ecol Evol 3:172-175

*Madsen PT, Wahlberg M, Tougaard J, Lucke K, Tyack P (2006) Wind turbine underwater noise and marine mammals: implications of current knowledge and data needs. Mar Ecol Prog Ser 309:279-295

Martin J, Tolon V, Morellet N, Santin-Janin H and others (2018) Common drivers of seasonal movements on the migration-residency behavior continuum in a large herbivore. Sci Rep 8:7631

Mayo CA, Ganley L, Hudak CA, Brault S, Marx MK, Burke E, Brown MW (2018) Distribution, demography, and behavior of North Atlantic right whales (Eubalaena glacialis) in Cape Cod Bay, Massachusetts, 1998-2013. Mar Mamm Sci 34:979-996

McCoy E, Burce R, David D, Aca EQ and others (2018) Longterm photo-identification reveals the population dynamics and strong site fidelity of adult whale sharks to the coastal waters of Donsol, Philippines. Front Mar Sci 5:271

McKinney JA, Hoffmayer ER, Holmberg J, Graham RT and others (2017) Long-term assessment of whale shark population demography and connectivity using photo-identification in the western Atlantic Ocean. PLOS ONE 12: e0180495

* Menz MH, Reynolds D, Gao B, Hu G, Chapman J, Wotton KR (2019) Mechanisms and consequences of partial migration in insects. Front Ecol Evol 7:403

Meyer-Gutbrod EL, Greene CH, Davies KTA (2018) Marine species range shifts necessitate advanced policy planning: the case of the North Atlantic right whale. Oceanography $31: 19-23$

NARWC (North Atlantic Right Whale Consortium) (2019) North Atlantic Right Whale Consortium Sightings database 4/15/2019. Anderson Cabot Center for Ocean Life at the New England Aquarium, Boston, MA

NARWC (2020) North Atlantic Right Whale Consortium Identification database 6/19/2020. Anderson Cabot Center for Ocean Life at the New England Aquarium, Boston, MA

NMFS (National Marine Fisheries Service) (2008) Endangered fish and wildlife; final rule to implement speed restrictions to reduce the threat of ship collisions with North Atlantic right whales. US Dep Commer, 50 CFR 224, Fed Reg 73:60173-60191

NMFS (2016) Endangered and threatened species; critical habitat for endangered North Atlantic right whale. Fed Reg 81:4838-4874

NMFS (2020) North Atlantic right whale (Eubalaena glacialis) vessel speed rule assessment. National Marine Fisheries Service, Office of Protected Resources, Silver Spring, MD. https://media.fisheries.noaa.gov/2021-01/FINAL_NARW_ Vessel_Speed_Rule_Report_Jun_2020.pdf?null

Nowacek DP, Johnson MP, Tyack PL (2004) North Atlantic right whales (Eubalaena glacialis) ignore ships but respond to alerting stimuli. Proc R Soc B 271:227-231

Ott RL (1994) An introduction to statistical methods and data analysis. Duxbury Press, Belmont, CA

Oxoli D, Prestifilippo G, Bertocchi D, Zurbaràn M (2017) Enabling spatial autocorrelation mapping in QGIS: the Hotspot Analysis plugin. Geoing Ambient e Mineraria 2: 45-50

Pace RM III, Corkeron PJ, Kraus SD (2017) State-space mark-recapture estimates reveal a recent decline in abundance of North Atlantic right whales. Ecol Evol 7: 8730-8741

Pace RM, Williams R, Kraus SD, Knowlton AR, Pettis HM (2021) Cryptic mortality of North Atlantic right whales. Conserv Sci Pract 2021:e346

Parks SE, Brown MW, Conger LA, Hamilton PK and others (2007a) Occurrence, composition, and potential functions of North Atlantic right whale (Eubalaena glacialis) surface active groups. Mar Mamm Sci 23:868-887

Parks SE, Clark CW, Tyack PL (2007b) Short- and long-term changes in right whale calling behavior: the potential effects of noise on acoustic communication. J Acoust Soc Am 122:3725-3731

* Parks SE, Urazghildiiev I, Clark CW (2009) Variability in ambient noise levels and call parameters of North Atlantic right whales in three habitat areas. J Acoust Soc Am 125: 1230-1239

* Parks SE, Johnson M, Nowacek D, Tyack PL (2011) Individual right whales call louder in increased environmental noise. Biol Lett 7:33-35

Parsons ECM, Birks I, Evans PGH, Gordon JG, Shrimpton JH, Pooley S (2000) The possible impacts of military activity on cetaceans in West Scotland. Eur Res Cetaceans 14: 185-190

พPaskyabi MB (2015) Offshore wind farm wake effect on stratification and coastal upwelling. Energy Procedia 80: 131-140

*Paskyabi MB, Fer I (2012) Upper ocean response to large wind farm effect in the presence of surface gravity waves. Energy Procedia 24:245-254

* Patrician MR, Biedron IS, Esch HC, Wenzel FW and others (2009) Evidence of a North Atlantic right whale calf (Eubalaena glacialis) born in northeastern US waters. Mar Mamm Sci 25:462-477

PCCS (Provincetown Center for Coastal Studies) (2005) Toward an ocean vision for the Nantucket Shelf Region Part I. Review of the environmental characteristics of the Nantucket Shelf Region. Part II. Management options for resource protection and sustainable uses. Provincetown Center for Coastal Studies Coastal Solutions Initiative, Provincetown, MA

Pendleton DE, Sullivan PJ, Brown MW, Cole TVN and others (2012) Weekly predictions of North Atlantic right 
whale Eubalaena glacialis habitat reveal influence of prey abundance and seasonality of habitat preferences. Endang Species Res 18:147-161

Pettis HM, Pace RM III, Hamilton PK (2020) North Atlantic Right Whale Consortium 2019 annual report card. Report to North Atlantic Right Whale Consortium. NARWC, Boston, MA

Pettis HM, Pace RM III, Hamilton PK (2021) North Atlantic Right Whale Consortium 2020 annual report card. Report to North Atlantic Right Whale Consortium. NARWC, Boston, MA

QGIS Development Team (2018) QGIS geographic information system. Open-Source Geospatial Foundation. https:// www.qgis.org

Quintana-Rizzo E, Kraus S, Baumgartner MF (2018) Megafauna aerial surveys in the wind energy areas of Massachusetts and Rhode Island with emphasis on large whales. Progress report submitted to the Massachusetts Clean Energy Center. New England Aquarium Anderson Cabot Center for Ocean Life, Boston, MA

Quintana-Rizzo E, O'Brien O, Baumgartner MF (2019a) Megafauna aerial surveys in the wind energy areas of Massachusetts and Rhode Island with emphasis on large whales. Monthly report No. 26: August 2019. Prepared for MassCEC, Boston, MA. New England Aquarium Anderson Cabot Center for Ocean Life, Boston, MA

Quintana-Rizzo E, O'Brien O, Baumgartner MF (2019b) Megafauna aerial surveys in the wind energy areas of Massachusetts and Rhode Island with emphasis on large whales. Monthly report No. 27: September 2019. Prepared for MassCEC, Boston, MA. New England Aquarium Anderson Cabot Center for Ocean Life, Boston, MA

Record NR, Runge JA, Pendleton DE, Balch WM and others (2019) Rapid climate-driven circulation changes threaten conservation of endangered North Atlantic right whales. Oceanography 32:162-169

Richardson WJ, Miller GW, Greene CR (1999) Displacement of migrating bowhead whales by sounds from seismic surveys in shallow waters of the Beaufort Sea. J Acoust Soc Am 106:2281

Robinson R, Crick HQP, Learmonth JA, Maclean IMD and others (2009) Travelling through a warming world: climate change and migratory species. Endang Species Res 7:87-99

Rolland RM, Parks SE, Hunt KE, Castellote M and others (2012) Evidence that ship noise increases stress in right whales. Proc R Soc B 279:2363-2368

Runge CA, Martin TG, Possingham HP, Willis SG, Fuller RA (2014) Conserving mobile species. Front Ecol Environ 12: 395-402

Saba VS, Hyde KJW, Rebuck ND, Friedland KD, Hare JA, Kahru M, Fogarty MJ (2015) Physical associations to spring phytoplankton biomass interannual variability in

Editorial responsibility: Ana Cañadas,

Durham, North Carolina, USA

Reviewed by: J. Roberts and 1 anonymous referee the US northeast continental shelf. J Geophys Res Biogeosci 120:205-220

Schick RS, Halpin PN, Read AJ, Slay CK and others (2009) Striking the right balance in right whale conservation. Can J Fish Aquat Sci 66:1399-1403

* Segtnan OH, Christakos K (2015) Effect of offshore wind farm design on the vertical motion of the ocean. Energy Procedia 80:213-222

Sharp SM, McLellan WA, Rotstein DS, Costidis AM and others (2019) Gross and histopathologic diagnoses from North Atlantic right whale Eubalaena glacialis mortalities between 2003 and 2018. Dis Aquat Org 135:1-31

Stone CJ, Tasker ML (2006) The effects of seismic airguns on cetaceans in UK waters. J Cetacean Res Manag 8:255-263

Stone KM, Leiter SM, Kenney RD, Wikgren BC, Thompson JL, Taylor JKD, Kraus SD (2017) Distribution and abundance of cetaceans in a wind energy development area offshore of Massachusetts and Rhode Island. J Coast Conserv 21:527-543

* Thompson PM, Lusseau D, Barton T, Simmons D, Rusin J, Helen B (2010) Assessing the responses of coastal cetaceans to the construction of offshore wind turbines. Mar Pollut Bull 60:1200-1208

Thomsen F, Lüdemann K, Kafemann R, Piper W (2006) Effects of offshore wind farm noise on marine mammals and fish. Biola, Hamburg, on behalf of COWRIE

* van der Hoop J, Corkeron P, Moore M (2017) Entanglement is a costly life-history stage in large whales. Ecol Evol 7: 92-106

Ward-Geiger LI, Knowlton AR, Amos AF, Pitchford TD, Mase-Guthrie B, Zoodsma BJ (2011) Recent sightings of the North Atlantic right whale in the Gulf of Mexico. Gulf Mex Sci 29:74-78

Whitehead H (2001) Analysis of animal movement using opportunistic individual identifications: applications to sperm whales. Ecology 82:1417-1432

Whitehead H (2007) Selection of models of lagged identification rates and lagged association rates using AIC and QAIC. Commun Stat Simul Comput 36:1233-1246

*Whitehead H (2009) SOCPROG programs: analyzing animal social structures. Behav Ecol Sociobiol 63:765-778

*Whitt AD, Dudzinski K, Laliberté JR (2013) North Atlantic right whale distribution and seasonal occurrence in nearshore waters off New Jersey, USA, and implications for management. Endang Species Res 20:59-69

*Wilhelmsson D, Malm T, Ohman MC (2006) The influence of offshore windpower on demersal fish. ICES J Mar Sci 63: 775-784

Wilson B, Hammond PS, Thompson PM (1999) Estimating size and assessing trends in a coastal bottlenose dolphin population. Ecol Appl 9:288-300

Wimmer T, Whitehead H (2004) Movements and distribution of northern bottlenose whales, Hyperoodon ampullatus, on the Scotian Slope and in adjacent waters. Can J Zool 82:1782-1794

Submitted: January 3, 2021

Accepted: May 27, 2021

Proofs received from author(s): July 13, 2021 